\title{
Building Blocks for High Quality Science Education: Reflections based on Finnish Experiences
}

Jari Lavonen

Department of Teacher Education, University of Helsinki •jari.lavonen@helsinki.fi

\begin{abstract}
This reflective paper will present some key characteristics of Finnish education policy and its implementation from the point of view of Science Education. Firstly, a short description of Finnish education context is presented. Secondly, curriculum design, instructional strategies and approaches to assessment are presented and discussed. All these topics are reflected from the point of view of teachers' daily activities.
\end{abstract}

\section{Introduction}

This is a reflective paper where building blocks for high quality education are looked at from the point of view of Finnish education policy and its implementation. The focus is in teachers' daily activities. Finnish education has received attention from policymakers and researchers since the release of the first Programme for International Student Assessment (PISA) results in 2002. This interest is a consequence of the excellent results achieved by 15-year-old Finnish students. These students achieved scores in reading-, mathematics- , and scientific-literacy assessments that were among the highest in 2000, 2003, 2006 and 2009 in OECD countries (OECD, 2007; 2010). Not only the high scores but also the low variation of performance in results is an important outcome of the education policy. Especially interesting is when the variation in scores is divided to variation of performance within schools and between, it turned out that the variation between schools has been the lowest in Finland out of all OECD countries. This means that schools are very similar and succeed in engaging all kinds of learners in learning.

\section{Finnish education context}

In Finnish education policy and its implementation educational equality is essential. According to this policy, students should have equal possibilities to learn and, therefore, education is free, including books, meals and health care. Schools do not "select" their students; instead there are school districts. However, parents have the possibility to "select" a school. (Laukkanen, 2008; Sahlberg, 2011; Niemi, Toom \& Kallioniemi, 2012)

One important consequence of the equality policy is effective special education. Its aim is to prevent drop out and support the learning of all students. The basic education act emphasises different levels of support for individual students. On the first level, students shall be entitled to remedial teaching. Tasks and goals for the lesson are personalised temporarily. The aim is that teachers should not consider students in their class as one unit Instead, teaching should be adjusted to meet the individual needs of each student. 
Therefore, it is impossible to design a universal lesson plan. The second level is enhanced support that needs pedagogical arrangements. The need for enhanced support is determined by multi-professional pedagogical assessment. The third level is special-needs support that consists of special-needs education and other support such as possible interpretation and assistant services. Altogether 47.000 children (8.5 \%) have been recognised as having a need for enhanced or special-need support. From these 47.000 children $53 \%$ are integrated into normal classes through inclusion (integration). This means that in all Finnish classrooms there are several students with special needs and they have an individual education plan. Moreover, the classrooms are in general heterogeneous because there are no private schools. The basic education act emphasises the role of teachers in providing education according to students' age and capabilities. (J ahnukainen, 2011).

Another characteristic of Finnish education is the culture of trust. Education authorities and national level education policymakers trust teachers who know, together with principals, headmasters and parents, how to provide the best education for children and youth in a certain district. Schools and teachers have been responsible for choosing learning materials and teaching methods since the beginning of the 1990s when the national level inspection of learning materials was terminated. Moreover, there have been no national or local school inspectors since the late 1980s. Teachers are valued as experts in curriculum development, teaching, and assessment at all levels (FNBE, 2004). Also, the parents trust teachers. According to PISA School Questionnaire data only 1.4 per cent of the schools reported constant pressure from many parents, who expect schools to help the students more to achieve high academic standards (In OECD the corresponding percentage was 26.1 per cent; OECD, 2007). It is no wonder then that the teaching profession in Finland has always enjoyed great public respect and appreciation (Simola, 2005). The teaching profession, especially at the primary level, is also very popular and teacher-education departments can select from among the nation's best students with the highest scorers in the upper secondary schools (J akku-Sihvonen \& Niemi, 2006).

The Finnish education context is challenging for teachers. For this reason all teachers are educated on masters-level programmes at universities. In fact, there has been a 30 year tradition of educating elementary teachers (grades 1-6) and secondary teachers (grades 712) on master-level programmes at universities. Classroom teachers teach almost all the subjects in elementary school, whereas secondary teachers typically teach two subjects in the lower and upper secondary school. (Jakku-Sihvonen and Niemi, 2006). Primary teachers are educated at the Faculty of Education. Secondary teacher education is organised in cooperation between the Faculty of the specific discipline and the Faculty of Education. The students take a major and a minor in the subjects they intend to teach. They participate in undergraduate courses at the subject department. These courses help students develop a deep understanding of subject-matter knowledge and concepts as part of the conceptual 
framework of the subject (Lavonen, Krzywacki-Vainio, Aksela, Krokfors, Oikkonen \& Saarikko, 2007).

A core in both primary and secondary teacher education is pedagogical studies. During their pedagogical studies, the students are supported to combine educational theories, subject knowledge, and their personal history. Their subject knowledge, knowledge about teaching, and learning in specific subjects and school practices are integrated into students' own personal pedagogical theories. According to the curriculum, students should, for example, be aware of the different dimensions of the teaching profession (social, philosophical, psychological, sociological, and historical bases of education), be able to reflect broadly on their own personal pedagogical "theory" or assumptions on their own work, and have the potential for lifelong professional development. Because, the student abilities are relatively heterogeneous in comprehensive schools, much emphasis is given to different types of learners, versatile planning of the teaching, teaching and learning methods and to teachers'roles, through formal and informal assessment and feedback and encouragement to students (Lavonen et al., 2007).

\section{Curriculum design}

A national office, the Finnish National Board of Education (FNBE), is responsible for the implementation of the national education policy through preparing a national framework curriculum and through organising national level monitoring (assessment) based on representative samples. However, the local education providers-the municipalities-have broad autonomy. They are responsible, with teachers, for planning local curriculum, organising assessment, and using these data to evaluate how well the goals in the curriculum have been achieved. According to PISA 2006 School Questionnaire data (OECD, 2007), a principal teacher and teachers feel that they are responsible for disciplinary policy (96.0 per cent of all respondents) and for assessment policy (97.0 per cent). These percentages are higher than the OECD averages-80.5 per cent and 76.9 per cent respectively. The local curriculum is seen as being more of a process than a product and it has a central role in school improvement. The role of a principal or a head teacher is important in school development and, moreover, in the implementation of educational policy at the local level.

The latest National Core Curriculum for Basic Education (FNBE, 2004) presents the values and mission of basic education in Finland:

"The underlying values of basic education are human rights, equality, democracy, natural diversity, preservation of environmental viability, and the endorsement of multiculturalism. Basic education promotes responsibility, a sense of community, and respect for the rights and freedoms of the individual." 
The core curriculum discusses also about learning, learning environments, operational cultures and teaching methods. The teaching methods used in the comprehensive school should help, support and guide a pupil's learning. The methods should also develop social, learning, thinking, working, and problem-solving skills, and foster active participation, creativity and use of information and communication technologies. Moreover, in the National Core Curriculum (FNBE, 2004), general goals and subject specific goals, basic concepts in each subject (short "syllabus"), and cross-curricular themes are described. The goals described in the National Core Curriculum are, from the point of view of legislation, "standards" (compared to law) and the municipalities and the teachers have to follow these guidelines. A minimum number of subject-specific lesson hours (comprehensive school) and courses (upper secondary education) are determined by the government. The lesson hours of all 13 school subjects in comprehensive school are located to grades, e.g. altogether 10 lesson hours in mathematics at grades 7 - 9. Based on the national framework curriculum, each municipality or even a single school prepares the local curriculum.

In the case of science, there is an integrated natural science in grades $1-4$ and separate physics \& chemistry and biology \& geography in grades 5 - 6 in Finnish primary school. Science subjects are taught by primary school teachers and there are on average 2.5 lesson hours per week. In lower secondary school (grades 7 - 9) science is divided into the separate subjects of physics, chemistry, biology, and health education. These are all taught by highly specialised secondary teachers.. According to content analysis of the goals for physics \& chemistry and biology \& geography, described in the National Core Curriculum, they are relatively similar with the competencies described in the PISA 2006 framework (Lavonen, 2007). The Finnish science curriculum emphasises activities where the students can identify, recognise or observe scientific issues within their activities and explain or interpret data or scientific phenomena, and draw conclusions based on the evidence. In Finland, practical work and demonstrations have long been accepted as an integral part of teaching and learning science subjects.

As a summary there are three special characteristics in Finnish curriculum design:

- The national level curriculum is a frame and municipalities and schools create a local curriculum. The local curriculum is both a process and a product. The process nature empowers teachers in planning processes and increases teachers' ownership in the curriculum.

- The aims, written in a general form, are most important in the curriculum - the syllabus does not exist in a traditional way. Form of learning outcomes is not used while writing the aims. The aims are written for grade groups, like $1-4$. Teachers have freedom in the implementation of the curriculum according to the aims. Moreover, they have freedom in the selection of teaching methods and teaching materials. 
- Equal value is given to all 13 school subjects at the primary and lower secondary level. The subjects are taught by highly specialised secondary teachers from the beginning of the lower secondary school (grades 7 - 12).

\section{Instructional strategies}

The concept "teaching method" is used in Finland as a synonym for a learning or instructional method/model/strategy or pupil activity or classroom practice designed to help students acquire concepts, ways of thinking, skills and values. Teaching methods are goal oriented and emphasise social interaction between students and teachers and between students.

In Finnish education, a metaphor Professionally Thinking Teacher (Koskenniemi, 1971) has been used to illustrate the ideal of a teacher, who takes into consideration goals in the curriculum, relevant pedagogical theories and research outcomes, in addition to his/her own experience when he/she is planning instruction and making decisions in each teaching/learning situation. The Professionally Thinking Teacher is an important aim in teacher education and students are guided to understand that a single teaching method is not a solution to all pedagogical problems in the classroom. For example, in physics and chemistry teacher education we have prepared a web-based learning environment in order to introduce several teaching methods suitable for science education, In the web-based environment, teaching methods are divided into four subsets: 1) experimental teaching methods, 2) teaching method that support social interaction, 3) teaching methods that support information processing and 4) teaching methods that support problem solving and creativity (generating of alternatives) (J oyce, Weil, \& Calhoun, 2003). There are several models of teaching in each subset. The descriptions of each model start with an introduction where the theoretical background of the model is given, e.g. how the model supports learning, and what is the learning psychological background of the model. Then, the syntax of the model is introduced through several examples, video-clips and animations. Furthermore, on the web-page there are information sections about assessment and different models of assessment.

Teaching methods are discussed in teacher education also in the framework of " $21^{\text {st }}$ Century Skills" movement. This movement refers to the redefining of the goals of education and how learning is organised in order to meet the demands of the $21^{\text {st }}$ Century (Trilling \& Fadel, 2009). There have been several endeavours, like OECD PISA and DeSeCo, aiming to describe, what students should learn in order to support them in personal, societal, and economic success. OECD (2005) takes competence in the DeSeCo-project to mean more than just knowledge and skills. It involves the ability to meet complex demands, by drawing on and mobilising psychosocial resources (including knowledge, skills and attitudes) in a particular context. DeSeCo identifies a small set of key competencies, rooted in a theoretical 
understanding how such competencies are defined. According to DeSeCo-project each key competency must "Contribute to valued outcomes for societies and individuals; help individuals meet important demands in a wide variety of contexts; and be important not just for specialists but for all individuals". Individuals need both critical and creative thinking and should be able to use a wide range of tools, like socio-cultural (language) and technological tools (Information and Communication Technologies, ICT) for interacting effectively with the environment; to engage and interact in a heterogeneous group; to take responsibility for managing their own lives and act autonomously. In current situation, aims for science education are emphasising critical thinking. This is easily seen in the PISA framework which emphasises three main competencies: identifying issues (questioning), making conclusions based on information and explaining phenomena. Therefore, there is hardly space for creative thinking and generation of ideas in science education.

However, choosing of the teaching methods which support students to learn "21st Century Skills" / competencies is not straightforward because students have diverse backgrounds and a variety of achievement levels which all affect their ability to learn. Therefore, it is important to utilise a variety of teaching methods which engages students in tackling the topic to be learnt in such a way that they create meaningful and understandable knowledge structures on the basis of a goal for learning. This type of meaningful learning is grounded on activity and intention, reflection and self-evaluation, collaboration and interaction, construction, contextualization, and cumulative learning (Bransford, Brown \& Cocking, 2000). In Finnish teacher education it is emphasised that previous characteristics of learning activity may also be realised through the use of ICT. For example, ICT allows students to engage with authentic, real-world situations, especially, the Internet provides access to knowledge worldwide through tools such as Google Earth (see more Jonassen, Howland, Marra \& Crismond, 2007).

In general, there is little research on Finnish classrooms. But, here some examples in the context of science are presented here. Juuti, Lavonen, Uitto, Byman \& Meisalo (2009) asked students in 75 randomly selected Finnish comprehensive schools in the $9^{\text {th }}$ grade (aged 15-16) about how physics and chemistry are taught and how they would like it to be taught. The most popular teaching methods in physics and chemistry were teacherdelivered or directed instruction. Demonstrations and practical work were the second most popular group of teaching methods. According to the survey, teaching methods emphasising creative thinking are almost newer used in Finnish science classrooms. Therefore, creative thinking and teaching methods which support collaboration and generating of ideas are in future introduced more widely in teacher education. In general, the students were quite satisfied with the teaching methods currently used. However, students stated that they would prefer teachers to more frequently hold classroom discussions concerning difficult concepts and problems. The students would like to do more project work, discuss in small groups or participate in a teacher lead discussion. 
The students participating in the PISA 2006 Scientific Literacy Assessment were asked: "When learning school science topics at school, how often do the following activities occur?" Finnish students consider that they frequently perform experiments and practical work by following the instructions of a teacher (or a workbook). Both teachers and workbooks guide students to make conclusions from experiments they have conducted. These activities happen on average more frequently in Finland than in other OECD countries. Teachers also actively present demonstrations. However, students are seldom allowed to design their own experiments or do investigations to test their own ideas. Finnish students think that in most lessons they are given opportunities to explain their ideas and express their opinions about topics. This kind of atmosphere is important for learning and motivation. In the classroom, a class debate or discussion occurs in some lessons. Finnish students consider that teachers are active members of the science class. They frequently explain how science ideas can be applied to a number of different phenomena and for understanding the world at large. Students also encountered the relevance of "broad science" concepts to their lives through explanations by their classroom teachers. (Lavonen \& Laaksonen, 2009)

One interpretation of the results on the use of teaching methods is that pupils perceive as being positive the fact that new concepts are introduced by a teacher, an expert, who first presents new information and then demonstrates how this information is used for solving problems or performing tasks. Moreover, students' experiments before and after the teacher-delivered sequences play an essential role in learning. Nevertheless, this does not mean that only teachers are talking, as there are also teacher-led discussions in science classes. Apparently, it is important that explanations of the discovered phenomena are presented and that conclusions are formulated, as well as their relevance to everyday life being shown built on the concepts, under the guidance of an expert (Bransford et al., 2000, p. 31). This works if the teacher has a central role in the classroom, which is also accepted by the majority of the students. According to Simola (2005), Finnish teachers believe in their traditional role and pupils accept their traditional position. There is also evidence, at least at the primary school level, that traditional teacher-centred instruction seems to result in higher academic performance than student-directed learning (Chall, 2000). Sociocultural ideas of learning have too often focused on pupil - pupil interaction without paying attention to the fact that the teacher plays a crucial role in acculturating pupils to the scientific way of thinking (Scott, 1998).

Lavonen and Laaksonen (2009) compared Finnish students' affective domain measurements in PISA to other student' measurements in other OECD countries and calculated a regression model which predict the students' performance in PISA. An important affective variable in PISA is self-efficacy which refers to the confidence students have in their abilities that they can successfully perform a particular task (Bandura, 1997). If a student believes he or she is unable to succeed in a task, this perception may lead to lower grades or an avoidance of science courses (Bandura, 1986). Finnish students' beliefs 
about Self-efficacy related to science was higher than in average in OECD countries and it was the most powerful positive predictor for Finnish students' performance in PISA 2006. Therefore, the Finnish science education culture has succeeded in supporting the development of students' science-related self-efficacy. According to Finnish national education policy, science teachers are the main actors in student assessment in comprehensive schools and, therefore, they can plan how to support and build students' confidence in their abilities when they need to perform a particular science task. Central in the assessment policy in Finland has been during the last 20 years to avoid ranking of schools or pupils and to avoid the feeling of punishment. This kind of long term policy has been important for the development of a supportive atmosphere to the development of selfefficacy (cf. Bandura, 1986). Finnish science classrooms are heterogeneous and can consequently offer low achieving students role models in the form of high achieving students (cf. Bandura 1997). Finnish science classrooms are relatively small and heterogeneous and, consequently allow common goal-setting and verbal persuasion, which takes the form of feedback and encouragement given by teachers to students. This kind of teacher behaviour could increase self-efficacy (Bandura, 1997).

\section{Approaches to assessment}

Assessment serves various functions in addition to assessment of student learning outcomes, e.g., improving classroom activities and student learning processes as well as monitoring the quality of education through testing. There are several users of assessment data and actors as well as organisational levels. The implementation of assessment can take various forms, e.g., formative and summative assessment and self-assessment. The tension between the functions and forms of assessment depends on the educational system and assessment policy.

There has been a critical discussion on top-down education policy and the consequences of this policy on teachers' assessment activities and use of the assessment data for making improvements to teaching and learning in the classroom (Baird, 2009). An example of a top-down policy is an outcome-based approach where assessment has been originally argued to increase the quality of teaching and learning. As a part of an outcome-based approach, intended learning outcomes are described and external nationwide assessment in order to evaluate how well the students have achieved these learning outcomes are organised (e.g., Spady, 2003). However, the simplistic idea of externally guided assessment through testing is seen as an approach that does not consider learning as a process. Furthermore, defining intended learning outcomes and having testing consolidates the phenomenon of 'teaching for the test' and refers to the unwanted and largely unintended consequences of testing. Selecting particular content areas or skills to be trained, having 
bias towards the whole set of goals of the curriculum, and the teaching of knowledge and skills that are easy to test are among the unwanted outcomes.

Recent research has focused on the shift towards internal, teacher-conducted assessment procedures like alternative and formative forms of assessment (e.g., Black \& Wiliam, 2003; Inbar-Lourie \& Donitsa-Schmidt, 2009). Some teachers all over the world find that top-down educational policy and bureaucratic measures or testing threaten their feeling of having expertise and their confidence as a school teacher (Inbar-Lourie \& Donitsa-Schmidt, 2009; Black \&Wiliam, 2003). Moreover, teachers might not consider the feedback information from external assessment pedagogically relevant for improving particularly their classroom activities and may instead see it as external control. Consequently, in the top-down policy, the assessment data is probably not used for improving classroom activities or seen as a positive support for enhancing student learning. In Finland we have had a long-standing policy on teacher-conducted assessment and teachers have been considered to be at the core of assessment by implementing and mediating assessment procedures. This type of internal, teacher conducted assessment policy supports teachers also to modify classroom practice. (Lavonen \& Laaksonen, 2009)

We have recently examined Finnish primary and lower secondary teachers' views on assessment and how they implement assessment as part of their teaching (Krzywacki, Koistinen \& Lavonen. 2012). According to several interviews, assessment is mainly carried out as an internally guided integrated element of teaching and learning. This is a consequence of educational context which emphasises internal teacher-conducted assessment. However, the nature of assessment practice is highly dependent on individual teachers. The autonomous role of teachers influences the way assessment is integrated as part of teaching and learning in Finnish classrooms: teacher-conducted assessment practices are various and take place primarily for improving teaching and learning inside the classroom. Finnish teachers face challenges on many levels when implementing assessment. And they are committed to addressing these demands and do it in individual ways. This, in turn, has implications on the design of versatile assessment tools and resources. There are challenges for improving assessment in Finland as well. Teachers need to know and develop what to assess, how to assess and how to use assessment data for different purposes in their classrooms. As Corno (1995) states, teachers should also modify their teaching methods and learning materials to match their students' needs, i.e. engage in adaptive teaching. The shift towards student-centred assessment practice, meaning that students should also have a role in carrying out assessment that is evidently a part of the learning process, is a also current challenge. 


\section{Science teacher education}

The Finnish science education context is challenging for teachers in ways described above. For this reason elementary and secondary teachers are educated on masters-level programmes at universities. In fact, there has been a 30-year tradition of educating elementary teachers (grades 1-6) and more than a 100-year tradition of educating secondary teachers (grades 7-12) on masters-level programmes. Elementary teachers typically teach all the subjects in an elementary school, whereas secondary teachers typically teach two subjects in lower and upper secondary schools (Jakku-Sihvonen and Niemi, 2006). Primary teachers are educated at the Department of Teacher Education. Secondary teacher education is organised in a cooperation between the department of the specific discipline and the Department of Teacher Education.

The secondary student teachers take a major and a minor in the subjects they intend to teach. They participate in undergraduate courses at the subject department. These courses help students develop a deep understanding of content/subject-matter knowledge and concepts as part of the conceptual framework of the subject. Teachers need this knowledge when they guide students in problem-solving activities or when they ask high quality questions and, moreover, when they organise formative and summative assessment activities (Lavonen, Krzywacki-Vainio, Aksela, Krokfors, Oikkonen \& Saarikko, 2007). The students also study pedagogical content knowledge within their masters level courses at the Departments of Physics and Chemistry. They especially become familiar with how to introduce a certain concept through a demonstration or through lab activities. Moreover, they learn how a certain concept is related to other concepts, natural laws and theories in a certain domain of knowledge during a course focusing on the meanings of concepts. Furthermore, they learn the historical and philosophical bases of the subjects they teach. Several activities within the courses support students in planning instruction. These three courses support the development of PCK (Lavonen, J auhiainen, Koponen, \& Kurki-Suonio, 2004). Moreover, PCK is learned during the pedagogical studies as described below.

A core topic in both primary and secondary teacher education is pedagogical studies. According to the curriculum of pedagogical studies, the students should become aware of the different dimensions of the teaching profession, like the social, philosophical, psychological, sociological, multicultural, and historical bases of education, and obtain a readiness for different kinds of partnerships, like school - home and school - society partnerships. The pedagogical studies supports the students to combine educational theories their subject knowledge as well as their personal histories (cf. Trotman and Kerr, 2001). The students should also obtain a readiness for co-operation with multiprofessional teams at the school level. In a multiprofessional team, for example, social workers, school psychologists and special education teachers collaborate and look after the wellbeing of school students. Furthermore, they should learn to reflect broadly on their own personal pedagogical "theory" or assumptions about their own work, and have the potential for 
lifelong professional development. Because, the student abilities are relatively heterogeneous in comprehensive schools, much emphasis is given to different types of learners, the versatile planning of the teaching, teaching and learning methods and to the teachers' roles, through formal and informal assessment and feedback and encouraging the students. During their pedagogical studies, the students are supported in integrating content and pedagogical content knowledge; educational theories, like theories of learning, motivation and self-efficacy; their own experiences of teaching and learning and, moreover, their experiences of school practices into their students' own personal pedagogical theories or views. Students plan, how to teach specific topics and also teach topics during their teaching practice. Moreover, there are micro-teaching sessions within the studies. Consequently, students acquire PCK in different situations.

An essential characteristic of primary and secondary teacher education in Finland is an emphasis on research orientation (J akku-Sihvonen and Niemi, 2006). From the point of view of this orientation, the student teachers learn how to consume and produce educational knowledge within their pedagogical studies (Gitlin, Barlow, Burbank, Kauchak \& Stevens, 1999; Pendry and Husbands, 2000; Reis-J orge, 2005). A student consumes educational-research-based knowledge when he or she combines theory and experience or interprets a situation during his/ her teaching practice. The capacity to produce educational knowledge is learned by students during their research methodology courses and while conducting their educational research projects (Bachelor, Pedagogical and Masters Dissertations) (Gore and Gitlin, 2004).

Teaching practice is altogether one third of the pedagogical studies. During the teaching practice, the students are supported to transform practitioner (practical) knowledge into professional knowledge through reflective activities and guided discussions in small groups. Reflection refers here to a process in which an experience is recalled, considered, and evaluated, in relation to learning from practice. Mentor teachers who supervise teaching practice at the teacher training school support student teachers in a meaning-making process through facilitating the setting of aims for teaching practice; making observations of one's own behaviour in practice; the describing of observations and experiences, and analysis of observations and experiences (Rodgers, 2002). The role of supervision during the practice is central, and a trained mentor teacher helps the student to include all the possible aspects of a teacher's work in their reflection. During the advanced-practice stage, the student teacher becomes increasingly independent, and the discussions with supervisors are expected to become deep and detailed.

\section{Discussion}

I have been looking at the ideal building blocks for high quality education through analysing the key characteristics of Finnish education policy and its implementation, 
especially from the point of view of teachers' daily activities and teacher education. The main outcome of the education policy analysis was that Finnish teachers have strong autonomy in curriculum design, in the choosing of instructional strategies and approaches to assessment. This autonomy is supported, firstly, through the master level teacher education which is supporting pedagogical thinking and autonomous decision making. Secondly, autonomy is supported through the cultural respect acconded to the teachers (Auguste, Kihn, \& Miller, 2010). Thirdly, Finnish education policy supports teachers in their autonomous role.

The Finnish educational system, contrary to the top-down systems of many other countries, is characterised by the devolution of decision power and responsibility at the local level: the local municipalities have to plan the local curriculum together with the teachers based on the National Core Curriculum (NCCBE, 2004). In practice, teachers have an important and influential role in school education and teaching and, moreover in assessment. This core idea is mediated in initial teacher education programmes. For example, teachers are educated in curriculum work and choose learning and assessment materials to be used in their classes and to design the ways how to use such resources in order to fulfill the requirements of the curriculum.

Finnish education policy and its implementation could be compared to the global education movements (Sahlberg, 2004). Several opposite trends can be recognised. During the last two decades, there have been three common features in education policies and reforms globally that have aimed to improve the quality of education, especially to raise student achievement (Hargreaves, Earl, Shawn \& Manning, 2001) but which have not yet become a part of Finnish educational policy.

Firstly, an important movement globally in the 1980s was the outcome-based education reform. This movement was followed in the 1990s, originally in Anglo-Saxon countries, by standards-based education policies, including centrally prescribed performance standards for schools, teachers and students. Nationwide testing of students' learning outcomes is also a part of an outcome-based policy. In Finland, flexibility, and decision making at the local and even at the classroom level have been the main guiding lines. In the Finnish education context external demands are not visible in everyday school practice to guide teachers' work, including their assessment practices. This kind of atmosphere supports teachers to develop their teaching and, moreover, students in learning and development of their self-efficacy.

The second common feature in global education policy has been the emphasis on (scientific) literacy and numeracy. As a consequence, the curriculum and, therefore, the teaching in schools in many countries places a strong emphasis on structural knowledge of systems, technical skills, and cognition. In the Finnish national framework curriculum broader aims are emphasised and all school subjects are emphasised giving equal value to all aspects of an individual's personal development, whether they be moral, creativity, 
knowledge or skills based. Through emphasising wide variety of aims, $21^{\text {st }}$ century competencies could be approached in order to support students in personal, societal, and economic success.

The third global trend has been consequential accountability systems for schools. Success or failure of schools and their teachers is often determined by standardised tests and external evaluations that only devote attention to limited aspects of schooling, such as student achievement in mathematical and reading literacy. Again in Finnish primary and lower secondary school another direction has been chosen: trust through internal teacher conducted assessment which is also connected to the improvement of teaching and learning. Moreover, the needs of individual students in the classroom and their learning are considered to be essential in the process, i.e. assessment for learning initiated by Black and Wiliam (2003). A culture of trust within the education system values teachers' and headmasters' professionalism in judging what is best for students and in reporting on the progress of their learning. However, in Finnish upper secondary (high) school there is a final examination, called matricular examination. Although, there is a long tradition for oganising this test and positive feelings to the test among parents and students, it certainly affect to the teaching and learning and emphasising of aims in upper secondary school.?

One important education movement in several countries has been the "No child is left behind" movement. In Finland this movement is taken seriously. Low variation in student performance in PISA assessment is a consequence of this policy. Consequently, the integration of all learners into learning activities in a classroom has been successful. The collaboration between special teachers and primary or secondary teachers is successful. Moreover, classroom practice and teaching materials including special materials supporting inclusion are successfully used.

One additional feature in Finnish comprehensive school concentrates on teaching subjects where the teacher are highly specialised in the subject. In particular, lower secondary school teachers in Finland study more subject knowledge than teachers in many other countries. During these subject courses the student teachers in Finland become familiar with the epistemological and ontological basis of the subject. This kind of knowledge is important at school when teachers are guiding students in different kinds of activities and problem-solving. Knowledge and skills learned in those activities are needed also in PISA items. 


\section{References}

Auguste, B., Kihn, P., \& Miller, M. (2010). Closing the talent gap: Attracting and retaining top third graduates to a career in teaching: An International and market research-based perspective. McKinsley \& Company.

Baird, J .-A. (2009). Editorial: Macro and micro influences on assessment practice. Assessment in Education: Principles, Policy \& Practice, 16(2), 127-129.

Bandura, A. (1986). Social foundations of thought and action: A social cognitive theory. Englewood Cliffs, NJ : Prentice-Hall.

Bandura, A. (1997). Self-efficacy: The exercise of control. New York: W.H. Freeman and Company.

Black, P., \& Wiliam, D. (2003). In praise of Educational research: formative assessment. British Educational Research J ournal, 29(5), 623-637.

Bransford, J.D. \& Donovan, S.M. (2005). How Students Learn Science in the Classroom. Washington, D.C.: National Academies Press

Chall, J .S. (2000). The academic achievement challenge: what really works in the classroom? New York: Guilford Press.

Corno, L. (1995). The principles of adaptive teaching. In A. C. Ornstein (Ed.), Teaching: Theory into practice (pp. 98-115). Boston: Allyn and Bacon.

Gitlin, A., Barlow, L., Burbank, M., Kauchak, D., \&Stevens, T. (1999). Pre-service teachers' thinking on research: implications for inquiry oriented teacher education. Teaching and Teacher Education 15, 753- 769.

FNBE (2004). National Core Curriculum for Basic Education 2004. Helsinki: National Board of Education.

Inbar-Lourie, O., \&Donitsa-Schmidt, S. (2009). Exploring classroom assessment practices: the case of teachers of English as a foreign language. Assessment in Education: Principles, Policy \& Practice, 16(2), 185-204.

J ahnukainen, M. (2011). Different Strategies, Different Outcomes? The History and Trends of the Inclusive and Special Education in Alberta (Canada) and in Finland. Scandinavian J ournal of Educational Research, 55(5), 489- 502.

Jakku-Sihvonen, R., \&Niemi, H. (Eds.) (2006). Research-based Teacher Education in Finland Reflections by Finnish Teacher Educators. Research in Educational Sciences 25. Turku: Finnish Educational Research Association.

J onassen, D.H., Howland, J ., Marra, R.M., \& Crismond, D P. (2007). Meaningful Learning with Technology ( $3^{\text {rd }}$ ed). Upper Saddle River, New J ersey: Pearson Merrill Prentice Hall.

J oyce, B., \&Weil, M., \& Calhoun, E. (2003). Models of teaching (7th ed.). Boston: Allyn \& Bacon.

J uuti, K., Lavonen, K., Uitto, A., Byman, R. \& Meisalo, V. (2009). Science Teaching methods preferred by grade 9 students in Finland. International J ournal of Science and Mathematics Education.

Koskenniemi, M. (1971). Elemente der Unterrichtstheorie. München: Ehrenwirth.

Krzywacki, H., Koistinen, L. \& Lavonen. J . (2012). Assessment in Finnish mathematics education: various ways, various needs. Paper presented in $12^{\text {th }}$ International Congress on Mathematical Education, 8 J uly - 15 J uly, 2012, COEX, Seoul, Korea.

Laukkanen, R. (2008). Finnish strategy for high-level education for all. In In N. Soguel \& P. J accard (Eds.), Governance and Performance of Education Systems, pp. 305-324. The Netherlands: Springer.

Lavonen, J . (2007). National science education standards and assessment in Finland. In D. Waddington, P. Nentwig \& S. Schaze (Eds.), Making it comparable (pp. 101 - 126). Berlin: Waxmann, 
Lavonen, J ., J auhiainen, J ., Koponen, I. \& Kurki-Suonio, K. (2004). Effect of a long term in-service training program on teachers' beliefs about the role of experiments in physics education. International J ournal of Science Education, 26(3), 309 - 328

Lavonen, J ., Krzywacki-Vainio, H., Aksela, M., Krokfors, L., Oikkonen, J . \& Saarikko. H. (2007). Pre service teacher education in chemistry, mathematics and physics. In E. Pehkonen, M. Ahtee \&J . Lavonen (Eds.), How Finns Learn Mathematics and Science. Rotterdam: Sense Publisher.

Lavonen, J ., \& Laaksonen, S. (2009). Context of Teaching and Learning School Science in Finland: Reflections on PISA 2006 Results. J ournal of Research in Science Teaching, 46(8), 922-944.

NCCBE (2004). National Core Curriculum for Basic Education 2004. Helsinki: National Board of Education.

Niemi, H., Toom, A., \& Kallioniemi, A. (Eds.) (2012). Miracle of Education: The Principles and Practices of Teaching and Learning in Finnish Schools. Rotterdam: Sense Publishers.

OECD (2005). Definition and Selection of Competencies (DeSeCo): Executive Summary. Retrieved March 14 2012, from http:// www.oecd.org/ dataoecd/47/61/35070367.pdf

OECD (2007). PISA 2006: Science Competencies for Tomorrow's World, Volume 1: Analysis. Paris: OECD.

OECD (2010). PISA 2009: Volume 2: Data. Paris: OECD

Sahlberg, P. (2011). Finnish Lessons. New York: Teachers College Press.

Scott. P. (1998). Teacher talk and meaning making in science classrooms: a Vygotskian analysis and review. Studies in Science Education, 32, 45- 80.

Simola, H. (2005). The Finnish miracle of PISA: Historical and sociological remarks on teaching and teacher education. Comparative Education, 41(4), 455-470.

Spady, W. G. (2003). Outcome Based Education. In Guthrie, J. W. (Editor), Encyclopedia of Education, $2^{\text {nd }}$ ed., pp. 1827-1831. New York: Macmillan Reference.

Trilling, B., \& Fadel, C. (2009). 21st century skills: learning for life in our times. San Francisco, CA: J ossey-Bass.

Trotman, J., \& Kerr, T. (2001). Making the Personal Professional: pre-service teacher education and personal histories. Teachers and Teaching: theory and practice, 7 (2), 157-171. 
